Paideusis

\title{
Rethinking Combative Dialogue: Comparative Philosophy as a Resource for Examining Models of Dialogue
}

\author{
Sarah A. Mattice
}

Volume 19, Number 1, 2010

URI: https://id.erudit.org/iderudit/1072322ar

DOI: https://doi.org/10.7202/1072322ar

See table of contents

Publisher(s)

Canadian Philosophy of Education Society

ISSN

0838-4517 (print)

1916-0348 (digital)

Explore this journal

Cite this article

Mattice, S. (2010). Rethinking Combative Dialogue: Comparative Philosophy as a Resource for Examining Models of Dialogue. Paideusis, 19(1), 43-48.

https://doi.org/10.7202/1072322ar
Article abstract

In this essay I am concerned with our understanding of philosophical dialogue. I will examine the most prevalent western model of dialogue-the combat model-and suggest some flaws in this model. I will outline concerns as to how standards for what counts as 'philosophical' are determined, and use this outline to frame preliminary objections to conceiving of philosophical dialogue as combative. Noting that philosophy is a socially and historically rooted practice, I argue that the view of philosophy as a kind of combat has its origins in features of ancient Greek life. Next, I will look to other cultures and traditions for differing conceptual resources. Specifically, I look to ancient China's philosophical narrative as one that does not primarily conceive of philosophy in terms of combat. I conclude by suggesting the relevance of this inquiry into methodology for practices of teaching philosophy.
This document is protected by copyright law. Use of the services of Erudit (including reproduction) is subject to its terms and conditions, which can be viewed online.

https://apropos.erudit.org/en/users/policy-on-use/ 


\title{
Rethinking Combative Dialogue: Comparative Philosophy as a Resource for Examining Models of Dialogue
}

\author{
SARAH A. MATTICE \\ University of Hawai'i at Mānoa, USA
}

\begin{abstract}
In this essay I am concerned with our understanding of philosophical dialogue. I will examine the most prevalent western model of dialogue - the combat model_ and suggest some flaws in this model. I will outline concerns as to how standards for what counts as 'philosophical' are determined, and use this outline to frame preliminary objections to conceiving of philosophical dialogue as combative. Noting that philosophy is a socially and historically rooted practice, I argue that the view of philosophy as a kind of combat has its origins in features of ancient Greek life. Next, I will look to other cultures and traditions for differing conceptual resources. Specifically, I look to ancient China's philosophical narrative as one that does not primarily conceive of philosophy in terms of combat. I conclude by suggesting the relevance of this inquiry into methodology for practices of teaching philosophy.
\end{abstract}

\section{Framing Questions}

In the last century, comparative philosophers have made strides in promoting the understanding of divergent philosophical traditions. However, one realm has remained stubbornly outside mainstream comparative analysis - the structure of philosophical dialogue itself. There have been many attempts to demonstrate that non-western philosophical traditions meet the standards for philosophical discourse set by the ancient Greeks. However, little attention has been given to the question of whether or not we, as comparative philosophers, should examine our understanding of our own methodologies. In this essay I am concerned with the task of laying the groundwork for an exploration of methodology for philosophical dialogue. I will examine our understanding of philosophical dialogue as revealed in the most prevalent western model of dialogue - the combat model, the adversarial method, the argument as war metaphor-in order to suggest both that there might be flaws with this model and that it is not a necessary feature of dialogue.

If Ryle (2009) is correct and teaching is a kind of training in method, then philosophers must be aware of the models of and metaphors for their philosophical activities; these models may not be innocent, and training students in their use might have serious implications for the practice of philosophy. In other words, the how is important to the what. If to teach philosophy is some sense to teach how to dialogue with oneself and with others well, then the models for doing philosophy will set the standards for what counts as good dialogue.

In the 1950s, León-Portilla (1956) published his doctoral thesis, La filosofía Nabuatl (Philosophy of the Nahuatl people). The philosophical community at large greeted it with outrage, as he suggested

(C) Copyright 2010. The author, Sarah A. Mattice, assigns to Paideusis the right of first publication and educational and non-profit institutions a non-exclusive license to use this document for personal use and in courses of instruction provided that the article is used in full and this copyright statement is reproduced. Any other usage is probibited without the express permission of the author. 
that the indigenous people of northern Mexico had 'philosophy,' but one that did not match up with the standards for philosophy reaching back to Ancient Greece. Likewise, regarding the frequent questions as to the philosophical value of the Chinese philosophical traditions, Ni (2006) writes,

\begin{abstract}
As a reaction, many scholars tried to argue that they should be considered philosophy because they address similar concerns that Western philosophy addresses. This approach seems to enforce the idea that these are universal and eternal concerns, but one wonders also whether it is actually enforcing the idea that only Western philosophical concerns and Western conceptual frameworks are the primordial paradigm for philosophy and other concerns that do not fall neatly into the frameworks set by the Western model should either be kept outside of the game or distorted to fit into the game. (p. 19)
\end{abstract}

These are both examples of what Bernasconi (1997) calls the philosophical double bind. Either a non-centered group's thinking is so similar to the center (west)'s as to be uninteresting, or it is so different as to not count as 'philosophy.' For example, on this logic, we might say that if Mozi, a Warring States period Chinese philosopher, was a utilitarian, he wasn't as good a utilitarian as J. S. Mill, and so is not particularly valuable. Or, some might say, the Dao De Jing may be poetry or wisdom literature, but isn't really 'philosophy.' Behind this 'double bind' are unquestioned assumptions as to why the center's standards are what they are. Many of these assumptions are shaped by how we understand dialogue - in other words, what model or metaphor animates the center's conception of dialogue?

\title{
Philosophy as Combat
}

The boxing instructor or the philosophy tutor may enlarge his pupil's powers of defense and attack.

A professor once remarked to me that what he loved about doing philosophy was that it is like mental juu jitsu, and he is not alone. According to Moulton (1996), "the philosophic enterprise is seen as an unimpassioned debate between adversaries" (p. 152-3). This kind of languaging pervades our understanding of the activity of philosophy. The metaphor, identified by Lakoff and Johnson (1980), of argument as war, is sunk deeply into the ways in which we discuss and understand philosophical discourse. Because of the important role argument plays in philosophy, the metaphor extends not only to a discussion of argument, but also to philosophy as a whole. Lakoff and Johnson argue that the mapping between the conceptual fields of 'argument' and 'war' produces a shift in the domain of argument. Participants become adversaries, and the structure of dialogue becomes strategic maneuvering. The conversation begins with an initial volley, followed by a counterattack, posturing, surrender, victory, etc. And, the purpose of the argument, now painted with the war brush, is victoryto win, and to defeat your opponent.

Moulton (1996) identifies three main objections to what she calls the adversarial method (narrowly defined): It leads to misinterpretations of intellectual history, it limits the kinds of questions one asks and the kinds of answers one gives, and it can lead to bad reasoning.

In addition to these objections, there are several problems with this way of characterizing philosophical discourse. In what follows, I will give a brief sketch of several tension points arising from the meeting of combat and philosophical dialogue.

Internalization of Violence

With an understanding of philosophy as combat, philosophical dialogue with others becomes internalized as dialogue with oneself, which leads to approaching ourselves as combatants. Arendt (1971), among others, argues that we learn to be self-reflective through effective dialogue with others. 
However, when this dialogue with others is modeled on combat, it forces us to see the other participants as adversaries. When applied to ourselves, this means that we 'dialogue' with ourselves as our own adversaries. I argue that this is generally an unhealthy and only perversely sustainable relationship with oneself.

\section{Narrowing and Limiting of Possibilities}

If the purpose of the dialogue, understood as combat, is to win, then many other potentially fruitful avenues may not be explored. As Aristotle wrote in On The Heavens, "We are all in the habit of directing the inquiry to our opponent in argument, rather than to the subject matter in question" (Book 2 Part 13.3). What I do and think of in order to secure victory may not be in service of the topic or theme of the dialogue.

\section{Covering Over of Power Relations}

Combat begins with the (obviously) dubious assumption that all players are on a level playing fieldsoldiers attack other soldiers, not children, for example. In philosophical discourse this assumption manifests in the belief that any reasonable person is a fair adversary, and all adversaries are alike in being reasonable. However, in an actual dialogue, the power relations between the participants are not irrelevant, as they will influence the nature of each participant's response to the other. How I respond to a student is not identical to how I might respond to a teacher, or to a colleague, and this difference in response matters to the process of dialogue.

\section{Valorization of Hierarcbical Oppositional Reasoning}

Bordo (1988) identifies hierarchical oppositional reasoning-splitting things into two categories and then privileging one over the other-as the main problematic feature of the history of western philosophy. However, this is precisely what the combat model does. It encourages a dialectical split between camps and seeks to end with one side the victor. If Bordo is correct in identifying this kind of reasoning as problematic, then we should be wary of a metaphoric structure that influences us to think in that way.

\section{Possibility of Meta-Critique}

As a second-order activity, philosophy requires the ability to examine, assess, and alter its own practices and standards for practice. However, in a combat situation, soldiers, to a large extend, cannot and should not question what they are doing or why they are doing it. The idea in philosophical dialogue that all one's premises should, at least in principle, be fallible, is directly contradicted by the combat framing in which one's orders and the structure of battle itself are untouchable.

\section{Beginning to Rethink}

Where does this leave us? One option we have, if we accept that these objections are problematic and that the combat metaphor is problematic, is to go back and try to understand how this metaphor came to be in use, and whether or not it is necessary.

Sivin and Lloyd (2002) argue that a particular socio-historical situation in ancient Greece led to the combative nature of good thinking. To succeed as a philosopher depended entirely on one's ability to be orally convincing. One's livelihood rested on one's fame, which was decided in the public forum. And, to win a debate was to gain in fame. So it is not surprising that the realms of philosophy and of combat, both so prevalent in Greek culture at the time, came to be associated with one another. They further argue that 
The chief preoccupation of the up-and-coming philosopher or scientist, in all periods of Greco-Roman antiquity, was not to find a rich patron but to make a reputation among colleagues, often by confronting them directly in argument. It is this that stimulated, even if it did not dictate, much of the strident adversariality that is such a feature of Greek intellectual exchanges. (p. 103)

If the adversariality of philosophical discourse is, at least in some way, a socially and historically located feature - a side effect, as it were, of the predominance of Greek philosophy in the western traditionswe can look other established traditions in order to appreciate alternative understandings of philosophical discourse. If we are curious to find a philosophical tradition that emerged without any real emphasis on combat, we need look no further than China.

In most of the Chinese philosophical traditions, the understanding of how philosophy should be conducted was placed on consensus or harmony rather than certainty, on efficacy rather than victory. As Sivin and Lloyd (2002) argue, and as can be seen from studying the style of the commentary tradition, the movement of Chinese philosophical discourse is to show how others agree with youoften by using the authority of early texts. Chinese philosophy was not truth-seeking, but rather looked for the most effective way to lead one's person, family, and state to order. Thinkers seldom entirely rejected earlier theories in their proposals for new ones, and disciples didn't openly reject their teachers (contra the intellectual patricide so common in the Greek tradition). Rather, Lloyd and Sivin suggest that Chinese philosophers implied "their own superiority by conceding that others had a 'partial'-but only partial-grasp of the Way" (p. 249) while their own understanding was comprehensive. Additionally, philosophers in early China were usually employed by the government, not by their students, and so the need to distinguish themselves in a combative way didn't arise. Lloyd and Sivin argue that "The principal Chinese approach was to find and explore correspondences, resonances, interconnections. Such an approach favored the formation of syntheses unifying widely divergent fields of inquiry. Conversely, it inspired a reluctance to confront established positions with radical alternatives" (p. 250). Furthermore, as the noted scholar Wong (2000) argues, harmony (be), an important value in early Chinese thinking, was focused on consensus forming. The harmony striven for was not complete agreement, or single note harmony, but a concordance of differing perspectives, where everyone has had a genuine seat at the discussion table, so that even when an end choice is made, all have participated in creating it. The usual metaphors for harmony were cooking or music, where differing elements come together in a productive relationship.

As Hall and Ames (1987) explain, one of the reasons for certain differences in the problems and priorities between mainstream narratives in China and the west—and as I would suggest, what plays an important part in the differences in methodology - is a contrasting understanding of order. They identify a dominant form of 'order' in the west as logical order: an ordering where the parts conform to pre-established patterns/rules/laws, one consequence of which is absolute substitutability of the parts for one another. Aesthetic order, on the other hand, is characterized by the "emergence of a complex whole by virtue of the insistent particularity of constituent details" (p. 134). What does this have to do with philosophical dialogue? The absolute substitutability of participants in a dialogue understood as "combat" covers over the particularity of each participant, hides the power relations at play, and leads to an emphasis on a formal victory and final truth rather than on the process of the dialogue taken as a whole.

\section{In Closing}

When we take into account the wide variety of philosophical traditions available to us, we gain not only in terms of the quantity of ideas and philosophical positions, but also in terms of the ways in which we can approach philosophical dialogue. This is especially relevant when we consider the opening question 
of how we, as philosophers, are training others to think well. If we don't engage reflexively with our own 'styles' of doing philosophy, are we not unconsciously foisting onto others certain conceptions of what it means to be a good thinker?

\section{Acknowledgements}

This paper was presented in December, 2009, as Pluralist Implications: Rethinking the Combat Model of Dialogue, at The 38th Annual Meeting of the Philosophy of Education Society of Australasia, Honolulu, HI.

\section{References}

Arendt, H. (1971). Life of the mind. Orlando: Harcourt Press.

Aristotle. On the heavens. (J.L. Stocks, Trans.) Retrieved from http://etext.library.adelaide.edu.au/a/a8h/ Bernasconi, R. (1997). African philosophy's challenge to continental philosophy. In E. C. Eze (Ed.), Postcolonial African philosophy: A critical reader. Cambridge: Blackwell Publishers.

Bordo, S. (1988). Feminist skepticism and the 'maleness' of philosophy. The Journal of Philosophy, 85(11), 619-629.

Hall, D. L., \& Ames, R. T. (1987). Thinking through Confucius. Albany: State University of New York Press.

Lakoff, G., \& Johnson, M. (1980). Metaphors we live by. Chicago: University of Chicago Press.

Laozi. (2003). Dao De Jing: A philosophical translation. (R. T. Ames \& D. L. Hall, Trans.). New York: Ballantine Press.

León-Portilla, M. (1956). La filosofía nábuatl, estudiada en sus Fuentes (1a. edición), México: Instituto Indigenista Interamericano XVI.

Lloyd, G. \& Sivin, N. (2002). The Way and the word: Science and medicine in early China and Greece. New Haven: Yale University Press.

Mill, J. S. (1906). Utilitarianism. Chicago: University of Chicago Press.

Moulton, J. (1996). The adversarial method. In A. Garry \& M. Pearsall (Eds.), Women, knowledge, and reality. New York: Routledge Press.

Mozi (2003). Mozi: Basic writings. (B. Watson, Trans.) New York: Columbia University Press.

$\mathrm{Ni}, \mathrm{P}$. (2006). Reflections on comparative philosophy. The SACP Forum for Asian and Comparative Philosophy, 23(46), 19.

Ryle, G. (2009). Teaching and training. In J. Tanney (Ed.), Collected essays 1929-68, Vol. 2. New York: Routledge Press.

Wong, D. (2000). Fragmentation in civil society and the good. In L. Rouner (Ed.), Civility. Notre Dame, IN: University of Notre Dame Press.

\section{About the Author}

Sarah Mattice is a Ph.D. candidate in comparative philosophy at the University of Hawai'i at Mānoa. Her areas of specialization include comparative philosophy, classical Chinese philosophy, and continental philosophy. Her publications include ' $\mathrm{L} i$ and P4C: A case study of Confucian Li', in Comparative Philosophy Today and Tomorrow (2009), which she edited with J. Kimber and G. Ashton, and which was published with Cambridge Scholars Press. Her article 'On 'rectifying' rectification: Reconsidering Zhengming in light of Confucian role ethics' will be published in November 2010 with Asian Pbilosophy. She is working on a translation of a chapter from the Huainanzi, and is a co-editor for 
the essay collection Levinas and Asian Thought. She can be reached at mattice@hawaii.edu, and further information is available at http://manoa-hawaii.academia.edu/SarahMattice. 